原著

\title{
直立維持に抢沙随意性の検討
}

時田 喬1) 伊藤 八次 ${ }^{2)} \cdot$ 今岡 薰 ${ }^{3)}$. 福原 美穂 ${ }^{3)}$

\section{Voluntary Control of Standing Posture}

\author{
${\text { Takashi Tokital), Yatsuji } \text { Ito }^{2)} \text {, Kaoru Imaoka }}^{3)}$, Miho Fukuhara ${ }^{3)}$ \\ 1) Emeritus Professor, Gifu University School of Medicine \\ 2) Department of Otolaryngology, Gifu University School of Medicine \\ 3) Anima Corporation
}

Standing while making an effort to reduce postural sway (corrective standing, Cstanding) was compared with natural standing ( $\mathrm{N}$-standing) to study the peculiarities of voluntary control in standing posture. Sway of the body center of gravity was recorded with eyes open and closed with both feet close together for 60 seconds using a stabilometer.

1) Whilcoxon-test was used to compare the results. In C-standing with eyes open, the area and the ratio of low frequency bands on power spectra and the kurtosis of amplitude histogram on the $\mathrm{x}$-axis (right-left movement) increased and the length/area decreased. 2) Patterns of statokinesigrams showed a non-specific type or a right-left enlargement type in $\mathrm{C}$-standing with eyes open. 3) Autocorrelograms of body sway showed a loss of periodicity on the $\mathrm{x}$-axis in $\mathrm{C}$-standing with eyes open. 4) Attractors reconstructed from time series data obtained from the records showed a convergence of locus in the phase space on the $\mathrm{x}$-axis in $\mathrm{C}$-standing with eyes open.

Voluntary correction aimed at reducing the body sway in upright standing converted from rhythmic regular control (negative feedback control) depending on labyrinthine and proprioceptive reflexes to irregular adaptive control (positive feedback control) rely on visual information.

Key words: standing, autocorrelogram, attractor, voluntary control

\section{はじめに}

第一の目的は，直立姿勢の維持に扔いて随意性 がぞのよらな影響を持つか明らかにすることであ る。ヒトの直立は, 視性・迷路性・隹髄固有反射 などの姿勢反射，それを統御する中枢神経の働

\footnotetext{
1)岐阜大学名誉教授

2) 岐阜大学医学部高次情報統御学講座平衡・耳鼻咽喉 科学分野

3) $\boldsymbol{\gamma}=マ$ 株式会社
}

き, 小脳の協同運動機構, 大脳核の筇緊張制御機 構などの動きにより維持されているが，この直立 維持に随意性がどのように働くかは必ずしも明確 でない。姿勢反射が主役をしめる自然な直立と随 意的に直立動摇を小さくするよう制御した直立に 現れる重心動摇を比較し, 直立維持に打ける随意 性の働きを検討した。

第二の目的は, 重心動摇の評価をどのよらに行 らかを検討することである。重心動摇検査は日常 
の臨床検査として普及してきているが，その評価 には, 動摇面積, 単位時間軌跡長, 単位面積軌跡 長, 前後・左右偏倚, パワースペクトル，位置・ 速度べクトル，振幅ヒストグラムの標準偏差・歪 度・尖度など様々のパラメーターが用いられてい る。2002年の第61回日本めまい平衡医学会（会長

渡辺行雄教授）においてもこの体平衡機能評価 を如何にすべきかが指定演題として取り上げられ ている。第一の目的に揭げた直立に括ける随意性 の検討により得られた知見に基づき，重心動摇を どのよらな考苀に基づき評価すべきかを検討し た。

\section{方 法}

1. 被騟者

健常者は 6 名, 内訳は男性 5 名, 女性 1 名, 年 齢は22-55歳である。

\section{2 . 検討事項}

次の 2 条件に和ける直立を比較した。

条件A 自然な直立 (natural standing, NS)。 被験者には「楽に立って下さい」と指示した。

条件 B 随意的に摇孔を小さくするよら制御し た直立 (corrective standing, CS)。被験者には， 「真ん中に立つといら意識を持って立って下さい」 と指示した。

直立に関する他の指示，「足の体重の乗せ変克 はしない」「記録中，会話をしない」などは，日 本平衡神経科学会が提示した基準的検査 ${ }^{112)}$ と同 様である。

\section{3. 重心動摇記録と測定事項}

重心動摇計（アニマ社製5500）を用い，条件 A および B ておいて, 閉足にて開眼扣よび閉眼 時の重心動摇を各60秒間記録した。動摇記録は, 日本平衡神経科学会が提示した基準的方法 ${ }^{122}$ に 従って行った。サンプリング間隔は $50 \mathrm{msec}$ と した。サンプリング数は1200となる。記録した重 心動摇に特いて，次の測定・検討を行った。

1) 面積 (外周面積), 単位時間軌跡長, 単位 面積軌跡長, $\mathrm{X}$ 軸（左右）偏倚, $\mathrm{Y}$ 軸（前後） 偏倚, ロンベルグ率, $\mathrm{X}$ 軸・Y 軸パワースペク トル低・中・高周波数帯域面積比, 位置 - 速度べ クトル(左右方向, 前後方向), $\mathrm{X} \cdot \mathrm{Y}$ 軸振幅七 ストグラムの標準偏差, 昰度, 尖度を測定した。 条件 A，Bに括ける測定值を, 統計ソフト Statistica（Statosoft 社）を用い，「対応のあるウ
イルコクソン符号順位検定」を行った。

2）動摇型の判定。ニューラルネットを用いて 動摇型を判定した。既報334) の如く，典型的な動 摇型を示す例の測定値を入力してネットの学習を 行い，作成した荷重ネットに新しい例の測定値を 入力し, 出力值より動摇型を判定する方法であ る。ネット出力值が最も大さい值をもって，(1)開 眼記録では, 大動摇型, 低周波動摇型, 微細動摇 型, 前後抎大動摇型, 左右拡大動摇型, 高周波動 摇型, 求心動摇型, 前後動摇型, 左右動摇型を判 定した。なお，どの型のネット出力も0.5以下の 場合は非特異型とした。むた， 2 型以上で出力 0.5 以上を示す場合は混合型とした。計11型であ る。(2)閉眼記録では, 微細型を除く10型に分類し た。閉眼動摇分類に微細型がない理由は，ネット 作成過程で動摇型を抽出するために行った主成分 分析に执いて，この成分が検出されなかったため である4)。

3） $\mathrm{X} \cdot \mathrm{Y}$ 軸の自己相関図。相関図は，直立動 摇の平均的経過の観察に用いられている5 ${ }^{576}$ 。相 関分析は，重心動摇計に備わった解析・表示を用 いた。時間軸は土25.6秒である。相関図に沶い ては周期的振動の有無, 振動の周波数, 振動の減 衰の速さが観察対象となる。相関図のかたちは， 佐藤7)の記述を参考にして，次の 3 つに分けた。

(1)周期性：一定周期の摇孔の繰り返しを認めるも の。振幅の減少寸るものも含む。(2)持続性：遅延 時間零（相関値 1 ) から相関值が緩やかに（10秒 前後）で 0 に下がり，そのまま相関值零近傍の不 規則な摇れを示すもの(第 1 種)，零を越党負に なったのち再び零線に戻りその近辺に落ち着くも の (第 2 種)。(3)不規則性：遅延時間零（相関值 1) から相関值が $1 \sim 3$ 秒以内で急速に下がり以 後相関值零の線の近傍で周期性のない不規則な振 動を示するの。

4) アトラクタ (attractor)。アトラクタは, 散逸力学系 (エネルギーが逃げていく力学系) が 最終的に落ち着く運動を相空間（位相空間，状態 空間）に示したものである。軌道を引きつける性 貿からこのように呼ばれる。な拉，力学系は状態 点（物体の運動状態を想定する点）の運動をひき 起こす機構, 相空間は運動を記述する変数を座標 軸とする仮想的空間のことである8)。本研究では， 直立制御機構を 1 つの力学系之考光, 重心動摇の 
アトラクタにおいて随意性の影響を観察した。解 析対象とした時系列信号は, $\mathrm{X}$ 軸・ $\mathrm{Y}$ 軸の60秒 間の振幅值である。サンプリング間隔 $50 \mathrm{msec}$ なので1200個の值である。アトラクタ再構成は, 観測時系列から時間遅れ座標系への変換9)により 行った。すなわち，1つの時系列に対し，一定の 時間遅れ時系列を作り両者の 2 次元散布図を作成 する力法である。時間遅れの值ての設定には, いくつかの基準が提示されている。主要周期の数 分の 1 , 自己相関関数が最初に 0 となる洔刻など があるが，てが小さ過ざると再構成状態空間は極 端に相関が高くなり，2次元再構成状態空間で再 構成された軌道は，傾きが45度の直線近傍におし つぶされて分布し，逆にてが大き過ぎると各坐 標は無相関となり力学系の座標軸としては不適当 となる。本研究では, 自己相関図検査結果を参考 として，時間遅れの值 $\tau$ を 1 秒とした。

\section{結 果}

1. 測定値の平均値の検定

測定項目ごとの検定結果を表 1 亿示した。(1)開 眼検査では，自然な直立に対し随意的に制御した 直立においては，P 值0.05以下にて, 面積の増 加, 単位面積軌跡長の短縮, $\mathrm{Y}$ 軸パワースペク トル低周波数帯域面積比の増加, X 軸振幅ヒス トグラム尖度の增加を認めた。(2)閉眼検査では， 随意的制御を行った直立に括いて，P 值0.05以下
にて，Y 軸パワースペクトル高周波数帯域面積 比の減少を認めた。

以上, (1)随意的制御の影響は開眼直立で明膫に 現れた。(2)開眼にて, 随意的制御を行った直立で は自然な直立に較べ，面積，パワースペクトル低 周波帯域面積比, 尖度が増大し, 単位面積軌跡長 が短縮した。

\section{2. 動摇型の二ューラルネット分類}

(1)開眼直立における動摇型分類の結果を図 1 に 示した。随意的に制御した直立では自然な直立に 比べ5名が異なった動摇型を示した。5名の内, 左右拡大型加混合型 (症例 1 ), 混合型から非 特異型（症例 5 ）に変化した例が各 1 例, 求心型, 非特異型から左右拡大型へ変化した例（症例 3 ,

4) が 2 名, 混合型から大動摇型へ変化した例 (症 例 2) が 1 例であった。(2)閉眼直立における動摇 型分類の結果を図 2 に示した。随意的に制御した 直立に牤いて，自然な直立と同じ動摇型を示した 例 (症例 $1,2,5) \cdot か 33$ 例, 非特異型へ変化し た例（症例 $3 ， 6 ）$ が 2 名, 高周波型へ变化した 例（症例 4 ）が1名である。

以上，(1)開眼に执いて，随意的な制御により6 例中 5 例が動摇型の変化を示した。その内 2 例は 非特異型をたは混合型への変化, 2 例は左右拡大 型への変化であった。(2)閉眼では，自然な直立と 随意的に制御を行った直立で同じ動摇型を示した

表 1 自然な直立に対する随意的に制御した直立に打ける变化一重心動摇測定值に打いて一 （対応のあるウイルコクンン符号順位検定）

A: 面皘, LT: 単位軌跡長, LA: 単位面積軌跡長, XPWL: X 軸パロースペクトル低周波数帯域面積比, XPWH: X 軸ペワースペクトル高周波数带域面積比, YPWL: Y 軸パロースペクトル低周波数帯域面積 比, YPWH: Y 軸パワースペクトル高周波数帯域面積比, PVAE: 位置ベクトル前後方向, PVCG: 位置へ クトル左右方向, VVAE: 速度べクル前後方向, VVCG: 速度ベクトル左右方向, XSD: X 軸振幅七不卜 グラム標準偏差, XKRT: X 軸振幅ヒストグラム尖度, YSD: Y 軸振幅ヒストグラム標準偏差, YKRT: Y 軸振幅ヒストグラム尖度, R: ロムベルグ率

\begin{tabular}{|c|c|c|c|c|c|c|c|c|c|c|c|c|c|c|c|c|c|}
\hline \multicolumn{2}{|c|}{ 測定事項 } & A & LT & LA & XPWL & XPWH & YPWL & YPWH & PVAE & PVCG & VVAE & VVCG & $X S D$ & XKRT & YSD & YKRT & $R$ \\
\hline \multirow{2}{*}{ 開眼 } & P值 & 0.03 & 0.11 & 0.03 & 0.34 & 0.60 & 0.03 & 0.46 & 0.60 & 0.24 & 0.46 & 0.60 & 0.48 & 0.05 & 0.24 & 0.75 & \\
\hline & 判定 & 増加 & & 短箱 & & & 増加 & & & & & & & 增加 & & & \\
\hline \multirow{2}{*}{ 閉眼 } & P值 & 0.34 & 0.60 & 0.46 & 0.11 & 0.46 & 0.46 & 0.05 & 0.60 & 0.46 & 0.60 & 0.75 & 0.60 & 0.75 & 0.60 & 0.47 & 0.07 \\
\hline & 判定 & & & & & & & 隇少 & & & & & & & & & \\
\hline
\end{tabular}


Equilibrium Res Vol. 62(3)

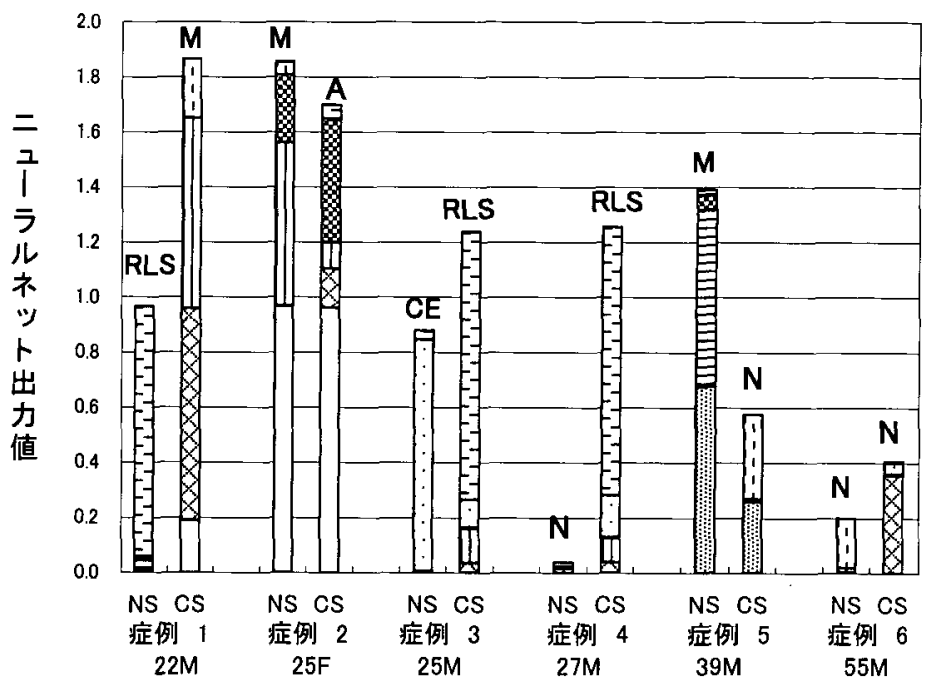

口左右動摇型系列(RLS)

口前後動摇型系列 (FBS)

曰求心型系列(CE)

回高周波型系列(HF)

日左右搪大型系列(RLE)

四前後拡大型系列(FBE)

因微細型(FS)

四低周波型系列(LF)

口大動摇型系列 (A)

どの型も出力0.5以下

非特異型 $(N)$

2型以上で出力0.5以上 混合型(M)

图 1 自然な直立 (NS) と随意的に制御した直立 (CS) の比較一開眼時の重心動摇型に枋いて一

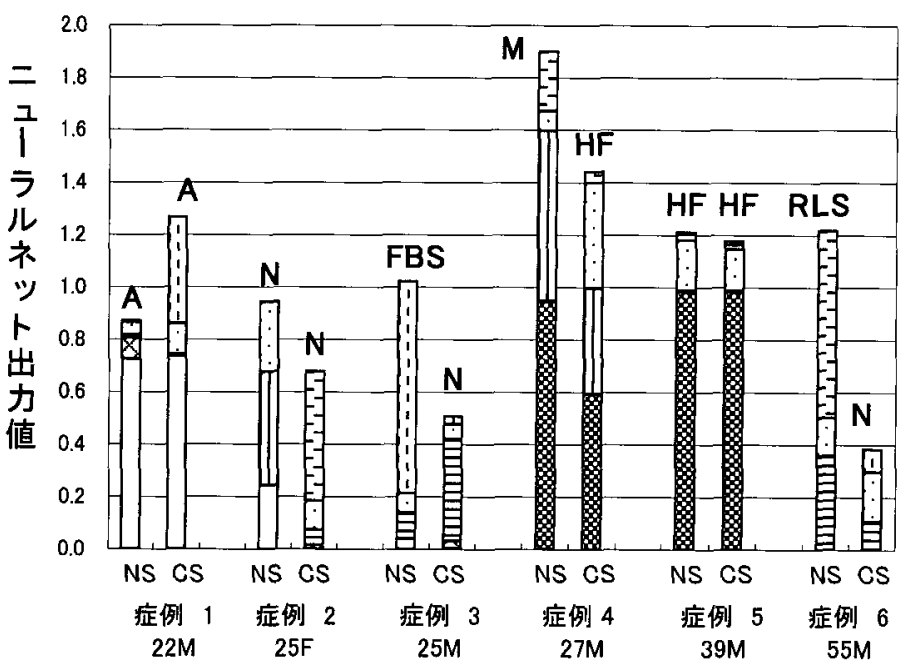

口前後動摇型系列(FBS)

曰左右動摇型系列(RLS)

曰求心型系列CE)

日左右拡大型系列(RLE)

四前後拡大型系列(FBE)

回高周波型系列(HF)

低周波型系列(LF)

口大動搯型系列(A)

どの型も出力0.5以下

非特異型 $(\mathrm{N})$

2型以上で出力0.5以上

混合型 $(M)$

図 2 自然な直立 (NS) と随意的に制御した直立 (CS) の比較一閉眼時の重心動摇型に打いて一

例が 3 例あった。動摇型の変化を示した 2 例は非 特異型への変化であった。

\section{3. 自己相関図}

図 3 亿, 症例 3 (25歳, 男性) の動摇図, 自己 相関図を示した。図左部は動摇の記録である。図 右部はこれより得た自己相関図である。相関図の 所見を述べる。(1)開眼検查のX 軸相関図では， 自然な直立に物いて約 $0.1 \mathrm{~Hz}$ の周期の振幅が減
衰する摇らぎを認めるが，随意的に制御した直立 ではこの周期性の摇らぎは消失している。 $\mathrm{Y}$ 軸 相関図では，自然直立では持続性（第 1 種）, 随 意的制御直立では持続性（第 2 種）である。(2)閉 眼検査の X 軸相関図では，自然な直立に扣いて 約 $0.2 \mathrm{~Hz}$ の摇れを認めるが，随意的に制御した 直立ではこの周期性の摇らぎは消失している。Y 軸相関図に招いては, 自然な直立では約 $0.3 \mathrm{~Hz}$ 

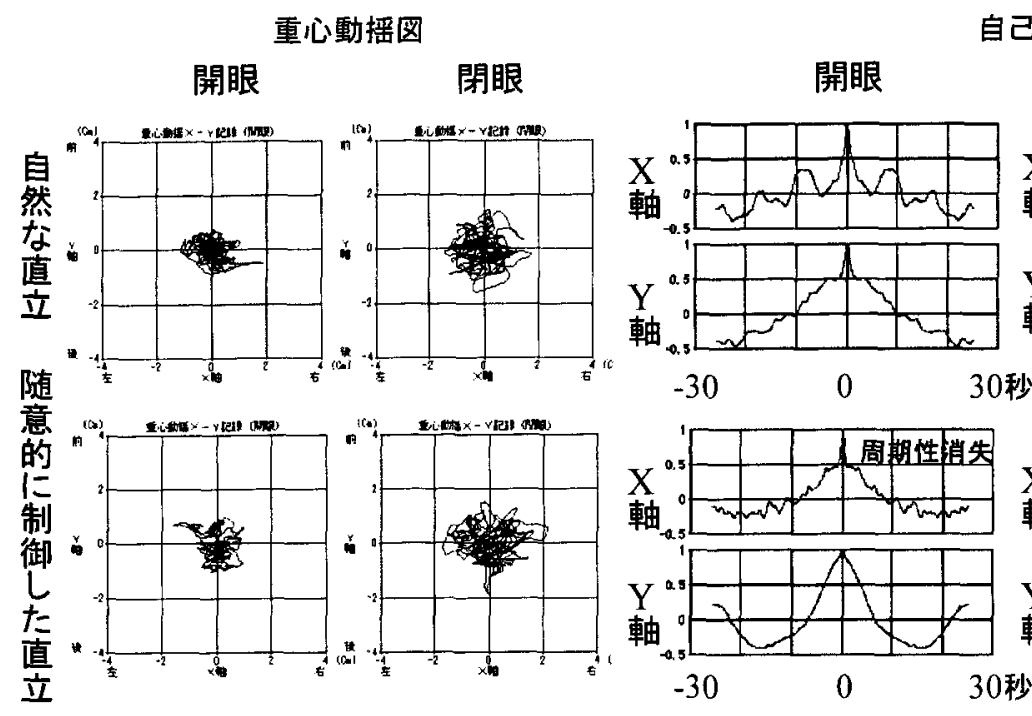

自己相関図
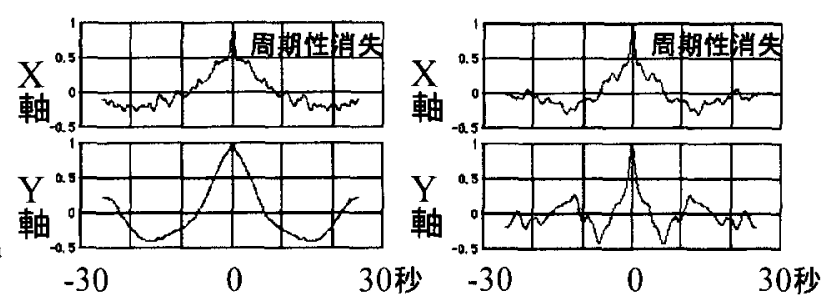

図 3 自然な直立と随意的に制御した直立の比較一重心動摇自己相関図に抽いて一

被験者 : 25歳, 男珄。

の周期性，随意的に制御した直立では持続性（第 2 種)である。

6 例の成績は, (1)開眼検査, $\mathrm{X}$ 軸相関図では, 6 例中 4 例に自然な直立で $0.1 \sim 0.5 \mathrm{~Hz}$ の周期性 摇らぎを認めたが，4例とも随意的に制御した直 立では周期性が啔失し，不規則性摇らざを示し た。自然直立で周期性を示さなかった 2 例は自然 な直立では減复性または不規則性で，随意的に制 御した直立では 2 例之も減衰性であった。 $\mathrm{Y}$ 軸 相関図では，自然な直立，随意的に制御した直立 とも持続性が 4 例, 周期型が不規則性となった例 が 1 例, 周期性が減衰性となった例が 1 例であっ た。(2)閉眼検査, X 軸相関図では, 自然直立で 6 例中 5 名に $0.1 \sim 0.5 \mathrm{~Hz}$ の周期性摇らぎを認 めたが，随意的制御直立で周期性を失い不規則性 摇らざとなった例が 3 例, 周期性が残った例が 2 名であった。1例は自然な直立, 随意的制御を行 った直立とも不規則であった。Y 軸相関図では， 自然な直立，随意的制御直立と夕不規則性または 減衰性が 3 例，持続性または不規則性から $0.1 \sim 0.2 \mathrm{~Hz}$ の崌い周期性となった例が 2 名, 周 期性から不規則性となった例が 1 名であった。

以上, (1)開眼, $\mathrm{X}$ 軸相関図では，4例が自然直 立で $0.1 \sim 0.5 \mathrm{~Hz}$ の周期性を示したが，随意的 制御直立では 4 例ともこの周期性が失われた。
軸相関図では，自然な直立，随意的制御直立と 6, 減哀性, 持続性, 不規則性を示す例が多かっ た。(2)閉眼，X 軸相関図では，5 例が自然直立で $0.1 \sim 0.5 \mathrm{~Hz}$ の周期性を示し, 3 例では随意的制 御值立でこの周期性が失われたが，2 例では周期 性が残った。 $\mathrm{Y}$ 軸では, 自然な直立, 随意的制 御直立とも，減衰性，不規則性を示す例が多か。 た。随意的制御直立で遅い周期性を示した例もあ った。

4・アトラクタ

図 4 は, 症例 5 の動摇図とアトラタタである。 図左部は重心動摇図である。図右部はこれより得 たアトラクタである。アトラクタは, 重心動摇 $\mathrm{X}$ 軸・ $\mathrm{Y}$ 軸に特けるサンプリング值を横軸, この 時系列より1秒遅れの值を縦軸とした散布図で示 してある。(1)開眼, X 軸のアトラクタは, 自然 直立では無構造であるが，随意的制御直立では軌 跡が中心に収斂する傾向を認める。Y 軸では， 自然直立, 随意制御直立とも, $\mathrm{X}$ 軸随意的制御 直立に怙ける如き軌道の収斂は認めがたい。(2)閉 眼, X軸のアトラクタでは, 随意的に制御した 直立に扣いて軌道の収斂傾向を認める。Y 軸で は, 自然な直立, 随意的に制御した直立とも軌道 に収斂を認めがたい。

6 例の成績は, 随意的に制御した直立に括い 


\section{重心動摇図} 開眼
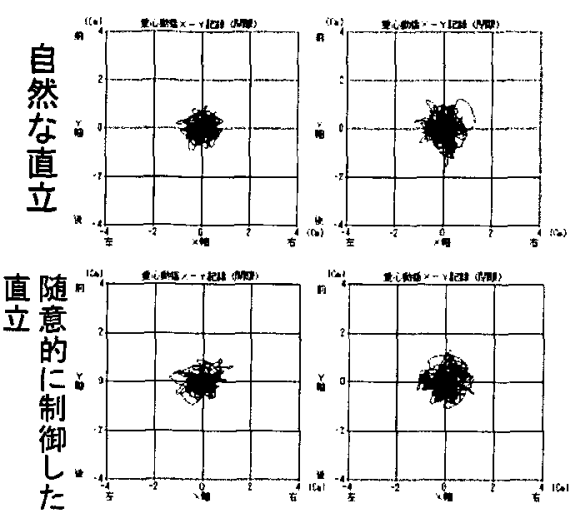

\section{アトラクタ}

開眼

$\mathrm{X}$ 軸
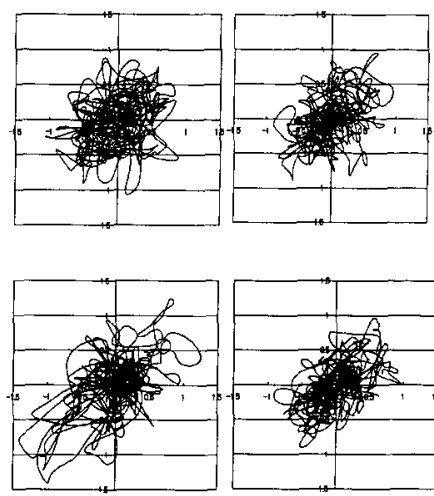

閉眼 $\mathrm{X}$ 軸 Y軸

軌道収斂

图 4 自然な直立と随意的に制御した直立の比較一アトラクタに扣いて一 被験者：39藏, 男性。

て，(1)開眼検查，X軸のアトラクタにおいて 5 例に軌道の収斂を認めた。Y 軸では軌道の収斂 を認めがたかった。(2)閉眼検查に拈いては，X 軸では 2 例, $\mathrm{Y}$ 軸では 2 例に軌道の収斂を認め た。

以上，(1)開眼，アトラクタは，自然な直立に較 べ随意的制御直立では軌道の中心への収斂を認め た。Y 軸では両者とも軌道は無構造であった。 (2)閉眼では， $\mathrm{X}$ 軸および $\mathrm{Y}$ 軸に拈いて，随意的 制御直立で各 2 例に軌道の収斂を認めた。

考 察

1．直立に扣ける随意性の検討について

動的な運動に打讨る随意性と姿勢反射の協働に ついては, 野球の捕球姿勢を始めとし各種の運動 姿勢10)，バレェの回転11)などに括いて研究され， 随意性は姿勢反射と協働して，運動能力を向上さ せていることが報告されている。これに対し，静 的な姿勢維持に牤いて随意性がぞのように働くか についての報告は少ない。Nishiwaki ら ${ }^{12)} は$ ， 楽に立つよらに指示した場合と摇れを小さくする ように立つよう指示した場合の直立を比較し，前 者に較べ後者では軌跡長が長くなることを報告し ている。山本ら ${ }^{13)}$ は, 自然体での立位と自発的 に摇れを抑えた立位での重心動摇をフーリエ解析 にて研究している。
2.直立における随意性について一観察結果よ 门一

(1)自然な直立と随意的に制御した直立に特ける 重心動摇測定值についての統計学的検定では, 随 意的制御を行った直立に拈いて自然な直立に較 ベ, 開眼に扣いて単位面積軌跡長の短縮, 面積, パワースペクトル低周波数帯域面積比, 尖度の増 大を認めた。随意的制御の影響は開眼直立に現れ 易く，随意的制御により動摇の面積は大きくな り, 摇れの周波数は低くなり, 摇れの微細さは減 少し，動摇振幅のヒストグラムが鋭鋒型になる。 このことは，随意的制御が視覚情報を手掛かりに 行われること，随意的調節は動摇面積を小さくす るものではないことを示している。

(2)動摇型の検討に扮いて，随意的制御による動 摇型の変化は閉眼より開眼に多く認められた。開

・閉眼とも非特異型变化する傾向が認められた が，開眼では左右動摇型への変化を示す例が存在 した。開眼に和いて, 動摇型が変化する傾向の多 いことは，随意的制御が視覚情報に依存して行わ れていることを示唆している。左右動摇が出現す る理由については, 視角より考学ると, 直立姿勢 の左右への変位・運動は, 前後への变位・運動よ り認識し易い。このため, 左右への姿勢調節が強 く行われるためと解积できる。な特，非特異型へ 
の変化については, 次に述べる相関分析の結果と あわせて，随意的制御では姿勢反射に依存する周 期性がある摇れが失われるためと考えている。

(3)自己相関図では, 開眼, 左右動摇, 随意的制 御直立に和いて自然な直立で現れていた周期性が 失われた。自然な直立では, 身体の摇らぎが刺激 となり視性反射, 迷路反射, 固有受容器性反射な どの姿勢反射が誘発され, 筋活動が起こり, 直立 姿勢の復元が行われるが，この動さは，再び，姿 勢反射受容器の刺激となり, 摇らぎながら姿勢の 復元・維持されている。すなわち，この姿勢反射 が中心となる姿勢制御は，值立姿勢を元の状態に 戻す方向へ働く負のフィードバックによる制御で ある14う。閉眼での自然な直立で周期性を認めるこ そが多いことは，この迷路反射, 自己受容性反射 の役割が大きい直立制御は周期性を示し易いこと を示唆する。随意的に摇孔を小さくするよらに調 節した直立ではこの周期性が裚失する。直立維持 に随意性が働く時には，元の姿勢に戻る負のフ ィードバック制御ではなく, 環境の変化に合わせ 自分を切り替えていく正のフィードバック15)に よる姿勢制御が行われていることによるものと解 积している。

(4)アトラクタの観察では, 開眼で随意的調節を 行った条件で左右動摇に和いて軌道が中心へ集ま る傾向を認めた。アトラクタは, 相空間での状態 点の動きの落ち着く先を示すが, 得られた所見 は，随意的調節により重心動摇が中心に集まるこ とを示するのと理解している。アトラクタが収斂 することで, 動摇型, 自己相関分析では得られな い, 直立制御に和ける随意性の働さの一面が観察 できたと考光ている。アトラクタの特徴を捉える ために, フラクタル次元解析，リアプノフスペク トル解析, リカレンスプロトと呼ばれる手法があ るが9), 今後の課題と考えている。

3. 重心動摇の評価について

重心動摇検査を用いて，直立における随意性に ついて検討したが，(1)測定值のグループ間の統計 的検討では, 開眼に蛙いて多くのパラメータに差 が現れること，開眼に括いて，面積が大きくな り, 動摇周波数は低くなり, 尖度が高くなること が把握できた。(2)動摇型による検討では，開眼に 扣いて随意性制御による型变化が出現すること, 変化として左右動摇型を示寸例があることが把握
できた。(3)自己相関図の検討では, 閉眼, 左右動 摇において動摇の周期性がなくなることが把握で きた。(4)アトラクタの検討では, 開眼で随意的に 調節した值立に执いて，動摇軌跡が中心に集まる 傾向のあることが観察できた。

以上の如く, 統計的検討とともに症例ごとに動 摇型, 自己相関関数, アトラクタを用いて多面的 に捉えることにより，直立に沏ける随意性の働き を明らかにすることができる。

な特，以上の観察では，個々の例に扣いて一回 の検查結果を基に，6例の成績より随意的調節し た直立に現れる性質を検討した。個々の例におけ る変化の再現性も 1 つ課題になるが，姿勢制御 系を，上述の如く，環境の変化侸わせ自分を切 り替克ていく正のフィードバックが働く系と考克 る時, 検査の繰り返しは直立に和计る状況变化を 与立，立ち方が切り替えられていく可能性があ る。重心動摇の検査に打いては，一回ごとの検査 で得られた結果を1つの所見と考え，その中に見 いだされる摇らぎの性質を洞察することが必要と 考觉ている。

\section{4. 直立制御系について}

「無数の構成要素からなる一をとまりの集団 で，各要素が他の要素とたえず相互作用を行って いる結果，全体としてみれば部分の動きの総和以 上の何らかの独自の振る舞いを示すもの」は複雑 系と定義されている16)。また，正のフィードバッ クは，複雑系では普遍的な仕組とされている15)。 直立制御は多数の制御系より制御され，各制御系 は相互作用があり，個々の制御系の働きのみで全 体の直立動摇は予測しがたい。また，直立制御に は姿勢反射による負のフィードバック制御と時に は随意性による正のフィードバック制御が働いて いる。直立制御系は複雑系と考光る必要がある。 複雑系の把握は多面的に行ら必要があるとされて いる15)。上述の成績も，重心動摇を多面的に捉觉 る必要があることを示結果であった。

\section{まとめ}

1. 直立姿勢制御において随意性の役割を明ら かにする目的で，自然な直立と随意的に摇れを小 さくするよらに制御した直立に抮ける重心動摇を 検討した。

1) 測定値の検定。(1)開眼検査に括いて，随意 的制御では, 開眼面積の増大, 単位面積軌跡長の 
减少, $\mathrm{X}$ 軸パワースペクトル低周波数帯域面積 比の增加, X 軸振幅ヒストグラム尖度の增加を 示した。(3)閉眼検査では, 随意的調節にてY 軸 パワースペクトル高周波数帯域面積比の減少を認 めるのみであった。

2 ) 動摇型。(1)開眼に和いて, 随意的に制御乙 た直立にて左右拡大型, あるいは特定の動摇型を 呈さない非特異型・混合型が観察された。(2)閉眼 では自然な直立と随意的直立に和いて同じ動摇型 を示す例が多かった。

3）自己相関図。開眼において，自然な直立で 認められた周期性が随意的制御を行った直立におる いて消失した。

4) アトラクタ。開眼において，随意的に制御 した直立では, 相空間に打ける軌跡の収斂が認め られた。

2. 重心動摇の評価について

1）重心動摇を用いて，自然な直立と随意的に 制御した直立の差を把握するためには, 測定值の 統計的検討とともに，個々の例に物いてパワース ペクトル，位置・速度へクトル・振幅ヒストグラ ム，相関図，アトラクタなどを検討することが必 要であった。

2 ) 複雑系と考光られる直立制御系の特性を把 握するためには，目的に適合した各種のパラメー タを検討する必要がある。

本稿は, 平成14年, 第61回日本めまい平衡医学 会（会長 渡辺行雄教授）で発表したものである。 擱筆するに当たり, ご教導戴いた徳島大学名誉教 授小池靖夫先生, 慶應大学竹内寿一郎先生に感謝 します。

文献

1) 日本平衡神経科学会: 重心動摇検查の基準.

Equilibrium Res 42: 367-369, 1983

2 ) 日本平衡神経科学会運営委員会（担当; 徳增 厚二, 田口喜一郎, 渡辺行雄) : 重心動摇検 査の Q \& A, 手引き（1995）. Equilibrium Res 55: 64-77, 1996

3) 時田 喬, 徳増厚二, 今岡 董, 他 : 二ュラルネットを用いた健常者の重心動摇の分
類. Equilibrium Res 60: 181-187, 2001

4) 時田 喬：重心動摇検查. 68-77頁, アニマ 社, 東京, 2002

5 ）時田 喬, 宮田英雄, 藤垣 熙, 他：直立時 の身体動摇の分析一動摇の多現象記録之相関 分析による一. 耳鼻臨床 63: 363-387, 1970

6) Tokita T, Miyata H, Matsuoka T, et al: Correlation analysis of the body sway in standing posture. Agressologie 17 B: 7-14, 1976

7 ）佐藤謙助：脳の情報処理（データ処理の手 法). 間田直幹, 内園耕二編. 新生理学上巻. 670-677頁, 医学書院, 東京, 1965

8) 科学シュミレーッション研究会：パソコンで 見る複雑系・カ才ス・量子、13-52頁, 講談 社, 東京, 1997

9）合原一幸：力オス時系列解析の基礎と応用. 13-80頁，121-198頁，産業図書，東京，2000

10) 福田 精: 運動と平衡の反射生理 (第 2 版). 1-43頁, 医学書院, 東京, 1980

11）時田 喬：からだのバランスー平衡生理学的 観点より一. JOHNS 14: 763-769, 1998

12) Nishiwaki $Y$, Takebayashi $T$, Imai $A$, et al: Difference by instructional set in stabilometry. J Vestib Res 10: 157-161, 2000

13）山本昌彦，吉田友英，野村俊之，他：自然立 位姿勢と自発性立位姿勢の体平衡変化につい て一FFT の詳細解析一. Equilibrium Res 6 1: 350,2002

14) Tokita T, Takagi K, Ito Y: Analysis of the vestibulo-spinal system with a five-dimensional feedback model. Acta Otolaryngol (Stockh) 104: 322-327, 1987

15）西山賢一：「複雑系」で, 不可解な世の中を 解く. 29-34頁, 198-202頁, ごま書房, 東 京, 1997

16）吉永良正：複雑系とは何か。1-20頁, 講談 社, 東京, 1997

$$
\left(\begin{array}{l}
\text { 原稿到着 : 平成15年 } 2 \text { 月 } 7 \text { 日 } \\
\text { 別刷請求先 : 時田 意 } \\
\mathbf{\Upsilon} 502-0851 \text { 岐阜市䉆山草平町 } 1476
\end{array}\right)
$$

